\title{
HLA-B27 associated cross-reactive marker on the cells of New Zealand patients with ankylosing spondylitis
}

L E McGUIGAN, A F GECZY, J K PRENDERGAST, J P EDMONDS, H H HART, ஹ AND $\mathrm{H}$ V BASHIR

From the Red Cross Blood Transfusion Service, Sydney, NSW, Australia

SUMMARY We have previously shown that antibodies raised in rabbits to certain enteric bacteria $\stackrel{0}{\circ}$ will specifically lyse, in a ${ }^{51} \mathrm{Cr}$ release assay, the peripheral blood lymphocytes (PBL) of $80 \%$ of $\tilde{\sim}$ HLA-B27 positive patients with ankylosing spondylitis $\left(\mathrm{B}_{2} 7^{+} \mathrm{AS}^{+}\right)$but not the PBL of HLA-B27 $\overrightarrow{+}$ positive normal controls $\left(\mathrm{B}_{2} 7^{+} \mathrm{AS}^{-}\right)$. Other laboratories have been unable to reproduce these findings. This study was designed to ascertain whether this lack of reproducibility was due to a peculiarity of our $\mathrm{B}_{27}^{+} \mathrm{AS}^{+}$patients or to technical difficulties in the complement mediated ${ }^{51} \mathrm{Cr}_{\vec{T}}$

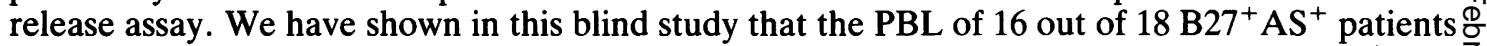
from a New Zealand population were lysed by our antisera but none of the PBL of $20 \mathrm{~B} 27^{+} \mathrm{AS}^{-}{ }_{\mathbb{D}}^{\frac{2}{2}}$ normal controls were lysed. The phenomenon of 'cross reactivity' between certain enteric bacteria and $\mathrm{B}_{2} 7^{+} \mathrm{AS}^{+} \mathrm{PBL}$ is not confined to the Sydney AS population.

Key words: enteric bacteria, lymphocytotoxicity, seronegative arthritis.

Although interest in the association between HLAB27 and ankylosing spondylitis (AS) has been intense, the mechanism by which the HLA-B27 gene or its product predisposes to the development of the disease remains unknown.

The initial observations of Ebringer et al. ${ }^{1}$ on the possible relationship between enteric organisms and AS prompted our group to search for 'cross reactivity' between Gram-negative bacteria and cells from patients with AS. We have been able to show that antisera raised in rabbits, initially to certain strains of klebsiella and subsequently to a number of enteric organisms, are able to recognise and lyse the peripheral blood lymphocytes (PBL) of $70-80 \%$ of patients with HLA-B27 positive ankylosing spondylitis $\left(\mathrm{B}^{2} 7^{+} \mathrm{AS}^{+}\right)$but not those of HLA-B27 negative spondylitics $\left(\mathrm{B}_{2} 7^{-} \mathrm{AS}^{+}\right)$or of the cells of HLA-B27

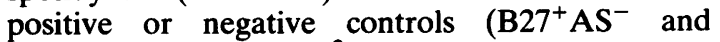
$\mathrm{B}^{-} 7^{-} \mathrm{AS}^{-}$respectively). ${ }^{2}$ Despite considerable early interest, these findings came to be regarded with

Accepted for publication 30 July 1985 .

Correspondence to Dr L E McGuigan, Australian Red Cross Society, Blood Transfusion Service, 153 Clarence Street, Sydney, NSW 2000, Australia. some scepticism because other laboratories wereष unable to raise antisera which reproduced our findings in a lymphocytotoxicity assay. ${ }^{34}$

The aim of the present study was firstly to attempt to validate our initial observations in an entirely new group of patients, and secondly, by using this different population group, to determine whether the failure of others to reproduce our findings was:due either to geographic variations in the expression?. of the B27 associated cross-reactive marker or to technical aspects of the lymphocytotoxicity assay. The study was structured to ensure complete objec-o tivity in the correlation of clinical status and assay? results by the use of a random code, held by one of the group, and broken only after all the laboratory and clinical data had been collected.

\section{Patients and methods}

PATIENTS

Patients with AS were selected from the rheuma-c tology outpatients attending the Auckland ors Middlemore hospitals in Auckland, New Zealand. The normal controls were selected from healthyō HLA-B27 positive blood donors in the same city. The 
Auckland population was chosen for several reasons: (a) cooperation of the rheumatologists and blood transfusion centre allowed ready availability of patients and controls; $(b)$ this population represented a discrete cohort of individuals quite different from the Sydney population on which our previous work was based; and (c) twice-daily air services between Auckland and Sydney provided rapid transfer of blood to the Sydney Red Cross Blood Transfusion Service.

From a group of 60 AS patients previously assessed clinically and radiologically ${ }^{5} 20$ patients were chosen on the basis of their availability and the unequivocal nature of the diagnosis. Two $\mathrm{B}^{-} 7^{-} \mathrm{AS}^{+}$ patients were included in the group. All 20 AS patients satisfied New York criteria. ${ }^{6}$

Twenty-five $\mathrm{B}^{2} 7^{+} \mathrm{AS}^{-}$individuals identified by the Blood Transfusion Centre in Auckland were contacted and asked to participate in the study as controls; 20 presented for assessment.

A relevant medical history, including the intake of non-steroidal anti-inflammatory drugs (NSAID), was obtained and the range of back and neck movements was assessed by standardised techniques in both patients and controls. ${ }^{7}$ These measurements were then compared with standards of age and sex matched controls. ${ }^{7}$ No radiographs were performed on the normal individuals. The characteristics of the patients with $\mathrm{AS}$ and of the $\mathrm{B} 27^{+} \mathrm{AS}^{-}$control group are shown in Table 1 .

Table 1 Characteristics of AS patients and HLA-B27 positive controls

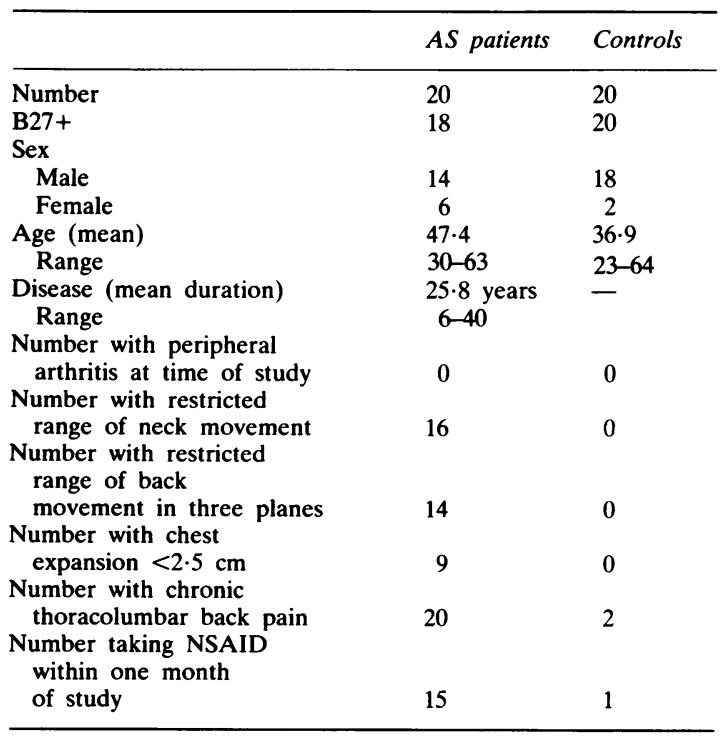

\section{METHODS}

From each patient and control individual $50 \mathrm{ml}$ of venous blood was obtained and placed in sodium heparin tissue typing tubes. The blood was transferred by air in an insulated container to Sydney where, on arrival at the Red Cross Blood Transfusion Service, it was randomly coded. The code was held by $\mathrm{Dr} \mathrm{H}$ Bashir and was not broken until all cytotoxicity assays and clinical evaluation had been completed.

\section{Cell preparation}

The PBL were separated from the blood by centrifugation in Ficoll-Paque (Pharmacia) for $25 \mathrm{~min}$ at $580 \mathrm{~g}$. The leucocyte band was removed and washed with RPMI 1640 (Flow) medium containing $2 \mathrm{ml}$ heparin (1000 units/ml), $10 \mathrm{ml} 1 \mathrm{M}$ HEPES ( $N$-2hydroxyethylpiperazine- $N^{\prime}$-2-ethanesulphonic acid, Sigma) buffer, $5 \mathrm{ml} \mathrm{L}$-glutamine $(200 \mathrm{mM})$, and $2 \mathrm{ml}$ penicillin-streptomycin (5000 IU, $5000 \mu \mathrm{g} / \mathrm{ml}$; Flow) per $500 \mathrm{ml}$ of RPMI medium. The leucocytes were suspended in RPMI 1640 medium containing 10\% human group $A$ serum and then centrifuged for a further $10 \mathrm{~min}$ at $180 \mathrm{~g}$. The leucocytes were resuspended in RPMI 1640 medium containing 10\% group A serum and adjusted to a cell concentration of $10 \% / \mathrm{ml}$ of medium. The cells were placed in an ice bath and an equal volume of $20 \%$ dimethyl sulphoxide in RPMI was added. All reagents and pipettes were cooled to $4^{\circ} \mathrm{C}$ before this addition. The cells were then placed in $2 \mathrm{ml}$ freezing vials in aliquots of $1 \mathrm{ml}$ each containing $5 \times 10^{6}$ cells. These vials were immediately placed in a controlled freezing cycle, frozen to $-100^{\circ} \mathrm{C}$, and then stored in liquid nitrogen.

\section{Antiserum production}

An Escherichia coli, previously identified as being capable of producing lymphocytotoxic rabbit antisera specific for HLA-B $27^{+} \mathrm{AS}^{+}$lymphocytes, was used to produce antisera. ${ }^{8}$ Other isolates of $E$. coli shown not to have this ability were used to raise negative antisera. ${ }^{8}$ These organisms were killed by adding $0.25 \mathrm{ml}$ of $40 \%$ formaldehyde to a $20 \mathrm{ml}$ suspension of the organisms $\left(10^{9}-10^{10} / \mathrm{ml}\right)$ in nutrient broth. The bacteria $\left(10^{9}-10^{10}\right)$ killed by formalin were washed twice with sterile $0.9 \% \mathrm{NaCl}$ and mixed with $2 \mathrm{ml}$ of complete Freund's adjuvant (Difco). This mixture was injected subcutaneously and intramuscularly into multiple (i.e., more than four) sites on rabbits (3-5 kg), whose serum had previously been shown not to contain antilymphocytic activity. Two weeks later each rabbit was boosted with a mixture of organisms and complete Freund's adjuvant, and 10-12 days later the animals received a further inoculation of cells in complete Freund's 
adjuvant. Four weeks after the initial injection the rabbits were bled and the serum stored at $-30^{\circ} \mathrm{C}$ until used in the cytotoxicity assay.

\section{Complement mediated lymphocytotoxicity assay}

Positive and negative antisera, as defined above, were tested on the PBL of the $\mathrm{B}_{2} 7^{+} \mathrm{AS}^{+}$and $\mathrm{B}^{2} 7^{-} \mathrm{AS}^{+}$patients and $\mathrm{B}^{+} 7^{+} \mathrm{AS}^{-}$controls. The frozen PBL were thawed in a water bath $\left(40-44^{\circ} \mathrm{C}\right)$ and gently agitated until the cell pellet was almost completely thawed. Each pellet was transferred to a $30 \mathrm{ml}$ plastic tube where $1 \mathrm{ml}$ of human group A serum was added dropwise followed by $1 \mathrm{ml}$ of RPMI 1640 medium. The tube was immediately filled with RPMI 1640 medium and spun at $180 \mathrm{~g}$ for $10 \mathrm{~min}$. The cells were then resuspended in $10 \mathrm{ml}$ of RPMI 1640 medium containing $10 \%$ group A serum and washed to remove any further trace of dimethyl sulphoxide. After this final wash the cells were resuspended in $1 \mathrm{ml}$ of RPMI 1640 containing $10 \%$ human group A serum and $100 \mu \mathrm{Ci}$ of ${ }^{51} \mathrm{Cr}$ (specific activity: $200-500 \mu \mathrm{Ci} / \mu \mathrm{g}$; Amersham) for $60 \mathrm{~min}$ at $37^{\circ} \mathrm{C}$. The cells were then washed twice with RPMI 1640 medium and resuspended in RPMI 1640 containing $10 \%$ human group $\mathrm{A}$ serum at a concentration of $2 \times 10^{6}$ cells $/ \mathrm{ml}$. $100 \mu \mathrm{l}$ of this ${ }^{51} \mathrm{Cr}$ labelled cell suspension was added to $10 \times 75 \mathrm{~mm}$ conical plastic tubes. The cells were incubated with $100 \mu \mathrm{l}$ of antiserum (undiluted) at $20-26^{\circ} \mathrm{C}$ for 40 min. Rabbit complement (100 $\mu \mathrm{l}$; Pel-Freez Biologicals) was added to each tube and the incubation continued for a further $75 \mathrm{~min}$. After the incubation with complement the cells were centrifuged at $400 \mathrm{~g}$ for $10 \mathrm{~min}$ and $100 \mu \mathrm{l}$ of the supernatant counted in a Beckman auto-gamma scintillation spectrometer. The amount of radioactivity in the samples was compared with the total release of ${ }^{51} \mathrm{Cr}$ from $\mathrm{PBL}$ $(100 \mu \mathrm{l})$ in the presence of $200 \mu \mathrm{l}$ of $1 \%$ Nonidet P-40 (NP40), while background release (i.e., release in the absence of antiserum) was calculated from the ${ }^{51} \mathrm{Cr}$ released from the PBL $(100 \mu l)$ in the presence of complement $(100 \mu \mathrm{l})$ and RPMI 1640 containing $10 \%$ human group A serum $(100 \mu \mathrm{l})$.

The results were expressed as the percentage of maximum ${ }^{51} \mathrm{Cr}$ released, which was calculated as follows:

\begin{tabular}{|c|c|c|}
\hline \multirow{2}{*}{$\%{ }^{51} \mathrm{Cr}$ release $=100 \times$} & $\begin{array}{l}\text { Radioactivity } \\
\text { released } \\
\text { by antiserum }\end{array}$ & $\begin{array}{l}\text { Radioactivity } \\
\text { released } \\
-\quad \text { in absence } \\
\text { of antiserum }\end{array}$ \\
\hline & $\begin{array}{l}\text { Radioactivity } \\
\text { released } \\
\text { by NP40 } \\
\text { solubilised cells }\end{array}$ & $\begin{array}{l}\text { Radioactivity } \\
\text { - released } \\
\text { in absence } \\
\text { of antiserum }\end{array}$ \\
\hline
\end{tabular}

Positive and negative antisera were used to test each patient's cells. All tests were done in duplicate and the cytotoxicity averaged. We have previously stated that ${ }^{51} \mathrm{Cr}$ release values $>50 \%$ are considered positive and values $<20 \%$ are negative. ${ }^{8}$ All lym $-?$ phocytotoxicity assays were performed by one of us (LMcG).

Assays were done once only on the cells of each음 patient and control, with the exception of one assay involving the cells of eight patients that had to be repeated because of unacceptably high background readings (i.e., $>80 \%$ of the NP40 total release).

\section{Results}

The results of the ${ }^{51} \mathrm{Cr}$ release cytotoxicity assays area diagrammatically presented in Fig. 1 . It can be seen that the $\mathrm{PBL}$ of 16 of the $18 \mathrm{~B} 27^{+} \mathrm{AS}^{+}$patientser showed cytotoxicity values $\geqslant 48 \cdot 6 \%$. The remainingi two $\mathrm{B} 27^{+} \mathrm{AS}^{+}$and both the $\mathrm{B} 27^{-} \mathrm{AS}^{+}$patients had ${ }_{\overrightarrow{+}}$ values of $<20 \%$.

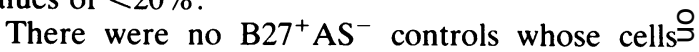
gave cytotoxicity values $>20 \%$ in the presence of positive antisera. The cytotoxicity values producedo

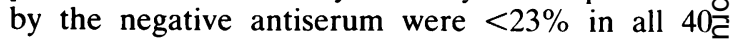
individuals tested (data not shown).

The two $\mathrm{B}^{+} 7^{+} \mathrm{AS}^{+}$patients whose PBL showed $<20 \%{ }^{51} \mathrm{Cr}$ release could not be distinguish\&d ${ }^{\circ}$ clinically from the other patients. Both were taki g. regular NSAID medication. It is pertinent that $\bar{\omega}$ f the five AS patients not taking NSAID medicatiôn four showed values of $>50 \%{ }^{51} \mathrm{Cr}$ release, while the other patient who was HLA-B27 negative had $<20 \%{ }^{51} \mathrm{Cr}$ release.

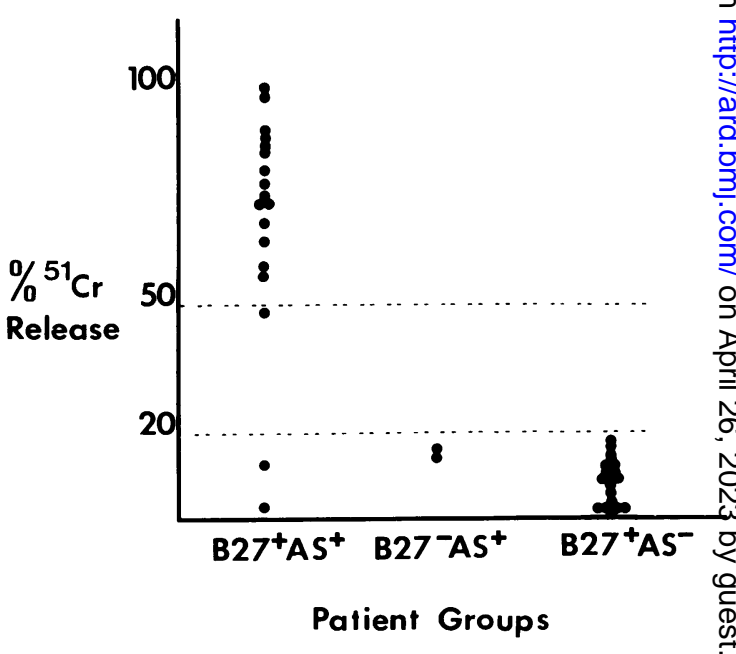

Fig. $1{ }^{51} \mathrm{Cr}$ release cytotoxicity values from $P B L$ of $B 27^{+} A S^{+}, B 27^{-} A S^{+}$patients and $B 27^{+} A S^{-}$normal controls. 


\section{Discussion}

It was the aim of this study to determine whether the inability of other groups to reproduce our results $^{349}$ was due either to an HLA-B27 associated antigenic determinant peculiar to the Sydney AS population or to technical problems associated with the cytotoxicity assay. The results described for the groups of $\mathrm{B}_{27^{+}} \mathrm{AS}^{+}$and $\mathrm{B} 27^{-} \mathrm{AS}^{+}$patients and the $\mathrm{B}_{27^{+}} \mathrm{AS}^{-}$controls allow several conclusions.

We have been able to confirm in an entirely new population our initial observations that certain antibacterial sera recognised and lysed PBL from more than $80 \%$ of $\mathrm{B}^{2} 7^{+} \mathrm{AS}^{+}$individuals but not the cells from $\mathrm{B}_{2} 7^{-} \mathrm{AS}^{+}$patients or $\mathrm{B}_{2} 7^{+} \mathrm{AS}^{-}$as controls.

To eliminate any possibility that the patients' clinical status might influence the interpretation of the assay result the assays were performed in a 'blind' manner. This was done by randomly coding blood samples as they arrived from New Zealand and having one member of the group (HVB), who was uninvolved in either the clinical assessment or the cytotoxicity assays, break the code only after all clinical and laboratory data had been finalised. It is clear from this study and from the work of Archer $e t$ al. ${ }^{10}$ reporting similar findings in a group of London AS patients, that the 'cross reactivity' phenomenon is not restricted to AS patients in Sydney.

It has previously been suggested that age and medication disparities between our $\mathrm{B}_{2} 7^{+} \mathrm{AS}^{+}$ patients and $\mathrm{B}_{2} 7^{+} \mathrm{AS}^{-}$controls could be responsible for our results. "I Although it is true that the $\mathrm{B} 27^{+} \mathrm{AS}^{+}$group in this study is older on average than the $\mathrm{B}^{2} 7^{+} \mathrm{AS}^{-}$group, their age range is similar, and it would be highly contentious to suggest this age disparity could be responsible for such a marked difference in the lymphocytotoxicity values we have reported. Similarly, it is very unlikely that NSAID treatment could be responsible for this phenomenon as there were four $\mathrm{B} 27^{+} \mathrm{AS}^{+}$patients who were not taking these medications and whose PBL gave high levels of lymphocytotoxicity and one $\mathrm{B} 27^{+} \mathrm{AS}^{-}$ normal donor who was taking NSAID medication whose PBL gave low levels of lymphocytotoxicity.

Thus it is possible to conclude that the failure of certain groups to reproduce our findings is unlikely to relate either to racial or geographic variations in the patients' expression of the HLA-B27 associated cross-reactive determinant or to drug or age related effects. It seems more likely that the difficulty relates to problems in raising antiserum or to the technique of the cytotoxicity assay itself. In that regard it should be noted that one of the nine assays performed in this study failed, in that very high background readings gave uninterpretable results.
Although we have not quantified in detail the relative importance of each variable in this assay system, this failure highlights the fact that all components, including the condition of the PBL, the media, and the complement, are critical to the outcome of the assay.

The explanation for the lack of corroboration by others is not clear. Perhaps it could be that there is a low density of the HLA-B27 associated crossreactive marker on $\mathrm{B}_{2} 7^{+} \mathrm{AS}^{+}$patients' cells, which may occasionally escape detection by some antisera. To minimise this possibility we always use undiluted sera in this assay. It could be argued that we may have been fortuitous in raising these specific antisera by our immunisation protocol, but as we have been able to raise antisera to a number of cross-reactive enteric organisms, all with the same specificity in over 22 different rabbits and several guinea pigs, it should be possible to repeat the procedure in other laboratories. However, until other groups are able to raise specific antisera to these organisms this relationship between AS and bacteria will remain controversial.

Even if the lymphocytotoxicity assay system can be reproduced by others it is not certain whether this relationship between enteric bacteria and AS is of pathogenetic significance to the disease process. Although we have previously presented some evidence as to how the cross-reactive determinant may be passed from bacteria to patients' cells, ${ }^{12}$ we do not know whether the presence of this determinant brings about the development of the pathological lesions of AS. We hope the possible mechanisms whereby this could occur will be investigated in detail when the relationship between these crossreactive bacteria and AS gains wider acceptance.

We acknowledge the National Health and Medical Research Council of Australia for grant support. We thank Dr G Woodfield and the staff of the Blood Transfusion Centre in Auckland for their assistance in providing normal HLA-B27 positive blood donors. We thank the Rheumatology Department of Auckland and Middlemore Hospitals for allowing us to see their patients.

\section{References}

1 Ebringer A. Cowling P. Ngwa S N. et al. Cross-reactivity between Klebsiella aerogenes species and B27 lymphocyte antigens as an aetiological factor in ankylosing spondylitis. In: Dausset J, Svejgaard A, eds. HLA and disease. Paris: INSERM, 1976: 27.

2 Seager K, Bashir H V, Geczy A F, et al. Evidence for a specific B27-associated cell surface marker on lymphocytes of patients with ankylosing spondylitis. Nature 1979; 277: 68-70.

3 Beaulieu A D, Rousseau F, Israël-Assayag E, Roy R. Klebsiella related antigens in ankylosing spondylitis. $J$ Rheumatol 1983; 10: 102-5.

4 Edmonds J, Geczy A F. Sullivan J S. Prendergast J K. Upfold L I, Bashir H V. Enteric bacteria and HLA-B27-associated cell surface modification in patients with seronegative spondarthritis. Br J Rheumatol 1983; 22 (suppl 2): 75-82. 
148 McGuigan, Geczy, Prendergast, Edmonds, Hart, Bashir

5 McGuigan L E, Hart H H, Gow P J, Kidd B L, Grigor R R, Moore T E. Employment in ankylosing spondylitis. Ann Rheum Dis 1984; 43: 604-6.

6 Bennett P H, Burch T A. New York symposium on population studies in the rheumatic diseases: new diagnostic criteria. Bull Rheum Dis 1967; 17: 453-8.

7 Moll $\mathbf{J}$ M H, Wright $\mathrm{V}$. Normal range of spinal mobility: an objective clinical study. Ann Rheum Dis 1971; 30: 381-6.

8 Prendergast J K, Sullivan J S, Geczy A F, et al. Possible role of enteric organisms in the pathogenesis of ankylosing spondylitis and other seronegative arthropathies. Infect Immun 1983; 41: 935-41.
9 Kinsella T D, Lanteigne C, Fritzler M J, Lewkonia R M. Absence of impaired lymphocyte transformation to Klebsiella spp. in ankylosing spondylitis. Ann Rheum Dis 1984; 43: 590-3.

10 Archer J R, Stubbs M M, Currey H L F, Geczy A F. An antiserum to Klebsiella K43 BTS 1 specifically lyses lymphocytes of HLA-B27 positive patients with ankylosing spondylitis from a London population. Lancet 1985; i: 344-5.

11 Kinsella T D, Fritzler M J, McNeil D J. Ankylosing spondylitis A disease in search of microbes. $J$ Rheumatol 1983; 10: 2-4.

12 Geczy A F, Alexander K, Bashir H V, Edmonds J. A factor(s) in klebsiella culture filtrates specifically modifies an HLA-B27associated cell surface component. Nature 1980; 283: 782-4. 